Chirurgia (2019) 114: 725-731

No. 6, November - December

Copyright@ Celsius

http://dx.doi.org/10.21614/chirurgia.114.6.725

\title{
The Impact of Bariatric Surgery on Diabetes and Other Cardiovascular Risk Factors
}

\author{
Elena Lechea', Mihaela Popescu ${ }^{2,3}$, Doina Dimulescu', Daniela Godoroja ${ }^{1,3}$, Catalin Copaescu ${ }^{1,3}$ \\ 'Ponderas Academic Hospital, Bucharest \\ ²Elias University Hospital, Bucharest, Romania \\ ${ }^{3}$ Carol Davila University of Medicine and Pharmacy, Bucharest, Romania
}

Corresponding author:

Roxana Mihaela Popescu, MD

Elias Cardiology Department

17 Marasti Blvd, Bucharest, Romania

E-mail: roxana.popescu@umfcd.ro

\section{Rezumat}

Impactul chirurgiei bariatrice asupra diabetului și a altor factori de risc cardiovasculari

Introducere: Obezitatea este o problemă majoră de sănătate publică în plină expansiune. Două treimi din decesele asociate obezitătii au cauză cardio-vasculară. Obiectivul studiului a fost comparația între factorii de risc cardiovascular înainte şi după chirurgie bariatrică.

Material şi Metodă: Studiul pilot retrospectiv a inclus 59 de pacienți consecutivi care au suferit intervenții de chirurgie bariatrică (gastric sleeve) în perioada ianuarie - martie 2016. Au fost urmariți urmatorii parametrii: BMI, circumferința abdominală, greutate, glicemie, trigliceride, LDL, HDL, necesarul de terapie antihipertensivă şi antidiabetică şi hemoglobina glicozilată la pacienții diabetici.

Rezultate: BMI, circumferința abdominală, greutatea corporală s-a redus cu $38 \%, 31 \%$, şi respectiv $41 \%$; glicemia s-a diminuat cu 16\%, trigliceridele au scăzut cu 37\%; HDL a crescut cu 18\%, LDL a scăzut cu $9 \%$. Au existat diferențe semnificative statistic (cu p <0.001) pentru toate variabilele cu excepția fracțiunii LDL a colesterolului. Necesarul de tratament antidiabetic a scăzut cu $60 \%$ şi cel de tratament antidislipidemic cu $21 \%$. La pacienți diabetici, hemoglobina glicozilată a scăzut cu $28 \%$ şi necesarul de tratament antidiabetic a scăzut cu $69 \%$.

Concluzii: Scăderea ponderală prin chirurgia bariatrică ameliorează sindromul metabolic pe toate componentele sale: dislipidemie, hipertensiune, hiperglicemie sau diabet zaharat tip 2, scăzând riscul de boală cardiovasculară. 
Key words: chirurgie bariatrică, factori de risc cardiovascular, diabet zaharat, sindrom metabolic

\begin{abstract}
Introduction: Nowadays, obesity is a major worldwide health problem due to its serious consequences and toits' increasing prevalence. Bariatric surgery has demonstrated a sustained weight loss and an efficient long-term control of the co-morbidities associated with obesity. The objective of our study was to compare cardiovascular risk factors before and after bariatric surgery. Material and Method: We have retrospectively studied 59 consecutive patients scheduled for bariatric surgery (gastric sleeve) in Ponderas Academic Hospital between January and March 2016, excluding the ones that didn't commit to respect the follow-up terms. The preoperative, 6 and 12 postoperative months blood tests and anthropometric measurements were comparatively analyzed. Results: BMI, waist circumference and total body weight decreased by $38 \%, 31 \%$, and $41 \%$; Glycemia, triglycerides and LDL cholesterol decreased by $16 \%, 37 \%$ and $9 \%$ respectively; HDL cholesterol increased by $18 \%$. The decline was statistically significant for all variables $(\mathrm{P}<0.001)$ except for LDL cholesterol. The need for antihypertensive treatment was reduced by $60 \%$ and for lipid lowering treatment diminished by $21 \%$. In diabetic patients glycated hemoglobin (HbA1c) decreased by $28 \%$ and the necessity for antidiabetic medical treatment dropped by $69 \%$.

Conclusions: Weight loss obtained by bariatric surgery in this study, improved the metabolic syndrome in all its components, obesity, hyperglycemia/type 2 diabetes, hypertension, and dyslipidemia, thus reducing the cardiovascular risk.
\end{abstract}

Key words: bariatric surgery, cardiovascular risk factors, diabetes, metabolic syndrome

\section{Introduction}

Obesity is a major worldwide health problem that is turning into a global epidemic due to its consequences and to the increasing prevalence in adults, as well as among children.

There was a significant increase in the prevalence of obesity worldwide in the last 40 years. Globally, more than 600 million adults and 100 million children were obese and in 2015 the prevalence doubled in 70 countries $(1,2)$.

Cross-sectional survey NHANES (National Health and Nutrition Examination Survey) data estimates age division for adults, finding a slightly higher percentage for ages between 40 and 59. Therefore, between ages 20 to 39 years, about $34 \%$ of men and $36 \%$ of women were obese, from 40 to 59 years old, about $40 \%$ of men and $44 \%$ of women were obese and, for ages above 60 years, 38 percent of men and 43 percent of women were obese (3).
Obesity is associated with a marked decrease in life expectancy and with an increased risk of all- cause mortality as it was highlighted in a meta-analysis of 230 cohortstudies and 30 million people (4). Mortality related to excess body weight occurred mostly due to cardiovascular conditions, exceeding two-thirds of all deaths (5). Overweight contributed to four million deaths globally and to more than 320,000 deaths in the United States in 20145. Cardiovascular disease (CVD) is the major consequence of obesity and that is the reason why body mass index (BMI) classifications are based upon its risk (5).

Numerous risk factors such as dyslipidemia, high blood sugar, obesity, smoking, chronic inflammation, high blood pressure are involved in the pathogenesis of cardiovascular diseases, especially in atherosclerosis as well as in type 2 diabetes and also in their evolutive complications.

The association of several of these risk 
factors constitutes the metabolic syndrome that partly overlaps with the insulin resistance syndrome. The metabolic syndrome is defined as an aggregation of major risk factors for cardiovascular disease and diabetes such as visceral obesity, atherogenic dyslipidemia, glycemic disorders and hypertension secondary to endothelial dysfunction, thus presenting as a major public health challenge. Abdominal obesity is the most frequently feature of metabolic syndrome.

Metabolic syndrome doubles the risk of atherosclerotic heart and cerebrovascular disease and it is responsible for four to five times increase in the risk of type 2 diabetes. It also multiples the risk of all-cause mortality by 1.5. The average prevalence of the metabolic syndrome in industrialized countries is $31 \%$. The average prevalence of the metabolic syndrome in obese patients is $60 \%$ (6).

Visceral obesity often leads to type 2 diabetes mellitus through the association of an increased need of insulin and a resistance to its effects leading to hyperinsulinemia and secondary, in time, to beta-cell dysfunction. The addition of these disorders to the secretion adipocyte cytokines (adipokines), and to chronic inflammation sustained by obesity promotes vascular endothelial dysfunction, hypertension, atherogenic dyslipidemia. All these mechanisms are involved in the development of atherosclerotic cardiovascular disease (CVD). Obesity is correlated not only with inflammation, but also with prothrombotic status, both independent, negative prognostic factors for cardiovascular disease, especially for atherosclerosis and thrombotic events.

More than half of adults with type 2 diabetes mellitus are obese with a BMI $\geq 30 \mathrm{~kg} / \mathrm{m}^{2}$; SHIELD (The Study to Help Improve Early evaluation and management of risk factors Leading to Diabetes) estimated 59\% and NHANES determined a percentage of $51 \%$. The values are striking if we take into account also overweight individuals, reaching $85 \%$ of all patients with type 2 diabetes (7).

Bariatric surgery produces marked and sustainable weight loss that ameliorates all the other risk factors for cardiovascular disease composing the metabolic syndrome: hyperglycemia/type 2 diabetes, hypertension, and dyslipidemia. Consequently, the risk of cardiovascular disease decreases after bariatric surgery. That is why, besides weight loss, bariatric surgery is mostly studied for its effects on metabolism, extensively demonstrated, leading to the use of "metabolic surgery" term, especially for diabetic patients $(8,9)$.

The objective of our study was to assess the impact of the weight loss obtained by bariatric surgery on the components of the metabolic syndrome and on other cardiovascular risk factors.

\section{Materials and Methods}

In this retrospective pilot study, we track the evolution of diabetes and other cardiovascular risk factors after bariatric surgery. At this moment, we retrospectively analyzed a group of 59 consecutive obese patients, which were subjected to bariatric surgery (laparoscopic sleeve gastrectomy) between January, $4^{\text {th }}$ and March 31 2016 in the Ponderas Academic Hospital, Bucharest. 145 obese patients underwent bariatric surgery within the 3 months studied interval. We have excluded the ones that didn't commit to respect the follow up evaluations and therefore, in their cases, the data was not available or incomplete for the present study. All the patients had an extensive preoperative evaluation consisting of blood tests, diabetes, cardiologic, psychologic and surgery consultations, abdominal echography, chest X-ray, IDEXA (DXA) scans, upper gastrointestinal endoscopy, barium enema, colonoscopy in patients over 45 years old, gynecologic and endocrinologic evaluations if needed.

The preoperative, 6 and 12 postoperative month's blood tests and anthropometric measurements were comparatively analyzed. We evaluated the evolution of different parameters such as: BMI, weight, waist circumference, serum glucose, glycated hemoglobin, liver enzymes, low density cholesterol, high density cholesterol, triglycerides, fibrinogen, the presence or the absence of hypertension, hypertension treatment and dyslipidemia treatment. 
All included patients completed and signed an inform consent approving the use of personal data for teaching or scientific purposes. The IRB approval was not necessary as this was a retrospective study and didn't involve access to identifiable private information.

All statistical calculations were performed using SPSS,versiunea...California, USA. The normal distribution for a continuous variable was tested using the Kolmogorov-Smirnov test. These were characterized as mean and standard deviation (SD) for variables with a normal distribution, or as median and range for variables with an abnormal distribution, respectively. Differences between comparative preoperative and postoperative variable values were determined by Paired T Sample Test, with a 95\% confidence interval and simple linear regressions. Statistical significance was set at $\mathrm{p}<0.05$.

\section{Results}

Patients in this group had ages between 28 and 74 years old, with a mean age of 51 years old, 33 of them were women and 26 were men. The maximum and minimum BMI before surgery was $67 \mathrm{~kg} / \mathrm{m}^{2}$, respectively $30 \mathrm{~kg} / \mathrm{m}^{2}$, with a medium BMI of $44 \mathrm{~kg} / \mathrm{m}^{2}$ and a medium waist of $132 \mathrm{~cm} .51$ of the patients $(86 \%)$ were hypertensive, 48 of them had chronic antihypertensive oral treatment and 3 of them were equilibrated by low salt diet. 22 $(37 \%)$ were diabetics, 11 of them were taking oral antidiabetic treatment, 2 of them insulin therapy plus oral antidiabetic treatment and the others were equilibrated by diet. The median values for LDL, HDL cholesterol and for triglycerides were borderline abnormal before surgery but $52 \%$ of the patients had chronic treatment with statins. All the patients underwent laparoscopic gastric sleeve and no perioperative morbidity or postoperative mortality was recorded in this cohort. The median hospital stay was 3 days after surgery.

Using Paired T Sample Test, with a 95\% confidence interval, comparing the mean values of the variables before surgery and at
12 months follow up, we obtained a favorable dynamic of almost all parameters.

BMI decreased by $38 \%$, from a mean value of $44 \mathrm{~kg} / \mathrm{m}^{2}$ to a medium of $27 \mathrm{~kg} / \mathrm{m}^{2}$, with a high statistical significance with $\mathrm{p}<0.001$. Waist decreased by $31 \%$, from a medium of $132 \mathrm{~cm}$ to a medium of $91 \mathrm{~cm}, \mathrm{p}<0.001$. Weight decreased by $41 \%$, from a medium of $129 \mathrm{~kg}$ to a medium of $76 \mathrm{~kg}, \mathrm{p}<0.001$ (Fig. 1).

Blood sugar decreased by $16 \%$, from a mean value of $107 \mathrm{mg} / \mathrm{dl}$ to a mean value of 89 $\mathrm{mg} / \mathrm{dl}, \mathrm{p}=0.001$. Triglycerides decreased by $37 \%$, from a mean value of $156 \mathrm{mg} / \mathrm{dl}$ to a mean value of $97 \mathrm{mg} / \mathrm{dl}, \mathrm{p}<0.001$. HDL Cholesterol increased by $18 \%$, from a mean of $48 \mathrm{mg} / \mathrm{dl}$ to a mean of $57 \mathrm{mg} / \mathrm{dl}, \mathrm{p}<0.001$. LDL Cholesterol decreased by $9 \%$, from a meanof $138 \mathrm{mg} / \mathrm{dl}$ to a mean of $125 \mathrm{mg} / \mathrm{dl}$, statically insignificant (See Table 1).

The necessary for antihypertensive treatment decreased by $60 \%$, only 19 out of 48 patients needed chronic medical treatment 12 months after surgery. The necessary for lipid lowering treatment decreased by $21 \%, 22$ out of 28 patients still had chronic treatment with statins 12 months after surgery.

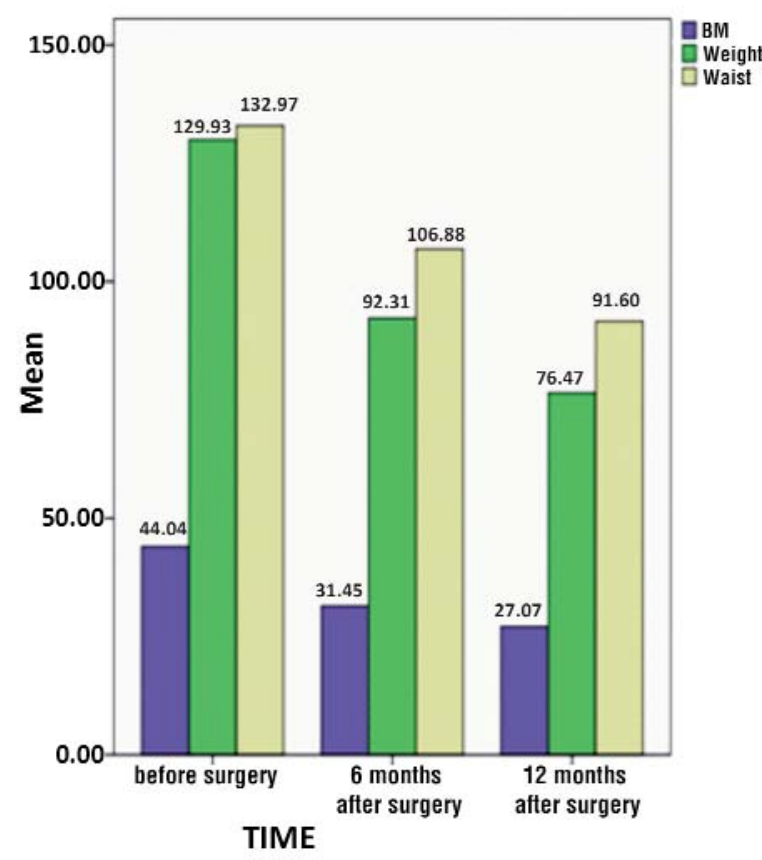

Figure 1. Variation of BMI (Body Mass Index), weight and waist after surgery 
Table 1. Variation of blood sugar; triglycerides, high- and low- density cholesterol before and after surgery

\begin{tabular}{|c|c|c|c|}
\hline Laboratory measurements & $\begin{array}{c}\text { Mean value } \\
\text { Before surgery }\end{array}$ & $\begin{array}{l}\text { Mean value } \\
\text { After surgery }\end{array}$ & $\begin{array}{c}p \\
\text { value }\end{array}$ \\
\hline Blood sugar mg/dl & 107 & 89 & $p<0.01$ \\
\hline Triglycerides mg/dl & 156 & 97 & $p<0.01$ \\
\hline High density cholesterol mg/dl & 48 & 57 & $p<0.01$ \\
\hline Low density cholesterol mg/dl & 138 & 125 & $p=0.11$ \\
\hline
\end{tabular}

Table 2. Variation of blood sugar; triglycerides, high- and low-density cholesterol before and glycated hemoglobin before and after surgery in diabetic patients

\begin{tabular}{lccc}
\hline Laboratory measurements & $\begin{array}{c}\text { Mean value } \\
\text { Before surgery }\end{array}$ & $\begin{array}{c}\text { Mean value } \\
\text { After surgery }\end{array}$ & $\begin{array}{c}\mathbf{p} \\
\text { value }\end{array}$ \\
\hline Blood sugar $\mathrm{mg} / \mathrm{dl}$ & 137 & 91 & $\mathrm{p}<0.01$ \\
\hline Triglycerides $\mathrm{mg} / \mathrm{dl}$ & 181 & 102 & $\mathrm{p}<0.01$ \\
\hline High density cholesterol $\mathrm{mg} / \mathrm{dl}$ & 45 & 57 & $\mathrm{p}=0.018$ \\
\hline Low density cholesterol $\mathrm{mg} / \mathrm{dl}$ & 124 & 119 & $\mathrm{p}=0.522$ \\
\hline Glycated Hemoglobin \% & 7.4 & 5.3 & $\mathrm{p}<0.01$ \\
\hline
\end{tabular}

For a subgroup of diabetic patients, using the same statistic method we obtained also a significant decrease of glycated hemoglobin by $28 \%$, from a mean value of $7.4 \%$ to a mean value of $5.3 \%, \mathrm{p}<0.001$ (Table 2).

Blood sugar decreased by $33 \%$, in the subgroup of diabetic patients, from a medium of $137 \mathrm{mg} / \mathrm{dl}$ to $91 \mathrm{mg} / \mathrm{dl}$, also statistically significant $\mathrm{p}=0.001$ (Fig. 2).

In diabetic patients the decrease in LDL cholesterol was statistically insignificant as well, only $4 \%$, from a mean value of of 124 $\mathrm{mg} / \mathrm{dl}$ to a mean value of of $119 \mathrm{mg} \mathrm{dl}$, and the increase of HDL cholesterol was $26 \%$, from a mean value of of $45 \mathrm{mg} / \mathrm{dl}$ to a mean value of of $57 \mathrm{mg} / \mathrm{dl}, \mathrm{p}=0.018$. None of the diabetic patients needed insulin therapy after surgery and the necessary of antidiabetic medical treatment decreased by $69 \%$ after surgery, only 4 out of 13 patients still had oral antidiabetic treatment 12 months after surgery.

Using simple linear regression, we established there was statistically significant association $(p<0.001)$ between weight and fibrinogen, and also for BMI and fibrinogen. For every 1 unit increase in weight, fibrinogen increased with 1.47 Units. For every 1 Unit increase in BMI, fibrinogen increased with 6.5 Units.

\section{Discussions}

Bariatric surgery improves lipid profile, especially triglycerides and HDL cholesterol. Clinical studies have demonstrated improved lipid profiles following bariatric procedures. RYGB (Roux-en-Y Gastric Bypass) is the most

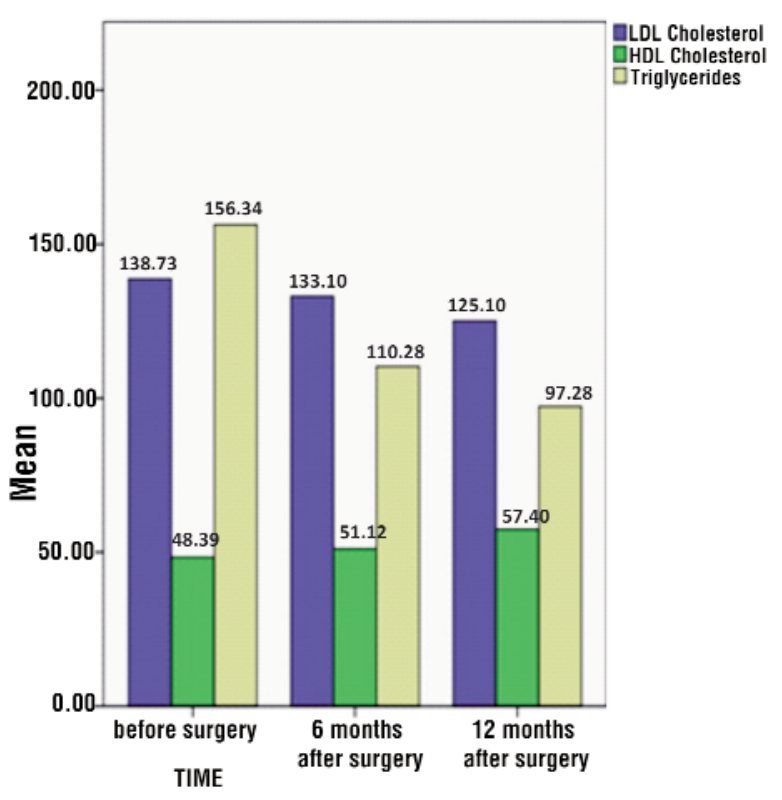

Figure 2. Variation of LDL (low density cholesterol, HDL (high density cholesterol) and triglycerides after surgery 
studied procedure in this matter (10-12,13).

The lower decrease in LDL Cholesterol in our study can be partly explained by the borderline values at the baseline, a significant difference is difficult to obtain when the baseline is normal. Moreover, $52 \%$ of the patients were already on chronic treatment with statins. Also, as there are numerous mechanisms involved in the increase of LDL cholesterol and that, in these types of disorders, lipid profile can be improved but not cured with diets and weight lost.

Blood sugar values registered a more accelerated decrease in the first 6 months, probably due to the low alimentary intake during the first months after surgery. Also, bariatric surgery has been shown to have important effect in glycemic rebalancing consisting of rapid decrease of hyperglycemia and of reduction of exogenous insulin necessary, which occurs early, even before obtaining significant weight loss. The fact that blood sugar and insulin levels normalize in a few days after surgery suggests that there are other mechanisms involved in improving glycemic disorders besides weight lost. It has been shown in experimental studies that the anatomical rearrangement of the gastrointestinal tract is the main mediator of the surgical control of diabetes (14). The medical explanation for these improvements is not yet completely understood but many factors other than improving of glucose utilization and decreasing of insulin resistance are noted as contributors, including changes in bile acid metabolism, gastro-intestinal tract nutrient sensing, and intestinal microbiomes $(15,16)$. An increase in glucagon-like peptide-1 (GLP-1) secretion after bariatric surgery is believed to be involved $(17,18)$. These combined changes, and perhaps others, reduce the production of hepatic glucose, improve peripheral tissue glucose uptake and the responses to insulin action, and prevents the decline of beta-cell function (15).

It is well known that weight loss, regardless of the way it is obtained, improves and it even gets remission of hypertension. GATEWAY trial, in which blood pressure was the primary endpoint, demonstrated the benefic effects of bariatric surgery on hypertension. The trial included 100 hypertensive and obese patients (BMI 30.0 to $39.9 \mathrm{~kg} / \mathrm{m}^{2}$ ) that were using medical lowering blood pressure treatment combining more than two classes of medication. A reduction of more than $30 \%$ of the total number of antihypertensive medications was observed in the $83.7 \%$ of the patients surgically treated. The same profile was obtained in only $12.8 \%$ of the control group. Remission of hypertension was present in about $50 \%$ of patients randomized to bariatric surgery (19). Also, patients treated with bariatric surgery have a greater probability of remission and lower chances of new onset of hypertension compared with medical treated patients as it has been shown in a single-center registry-based cohort study from Norway with a median follow-up of 6.5 years (20). Our results show a similar trend, with remission present in $60 \%$ of the hypertensive patients randomized. Longer retrospective analyses or prospective studies for recurrence or new onset of hypertension are necessary to enrich our results.

The limitations of the study are: the retrospective manner, the small number of patients included and the short follow-up period. Another limitation is that there is no control group study. The same group of patients is analyzed before and after surgery. A control group with similar characteristics, in which the weight loss is obtained through alternative acceptable methods, other than bariatric surgery would be useful for the strength of the study but it is very difficult to obtain such rates in weight loss using other approaches. The medium weight loss in this group was 53 kilograms during the first 12 months.

The strength of the study consists of the including consecutive patients, receiving surgery in single bariatric center, after passing an extensive preoperative protocol, and a strict postoperative follow up (different parameters according to the needs were evaluated at 1,3,6, 12 months after surgery and every year after that) that included lots of different measurements that make the study more accurate and 
can offer a response to different concerns that may arise. The outcomes' evaluation and analysis was performed by the team of the cardiologists.

According to the results obtained in this pilot study, bariatric surgery can be considered a treatment for diabetes and hypertension. Further analyses performed by multidisciplinary teams on larger group and longer follow-up are necessary.

\section{Conclusion}

As a result of remission or improvement of cardiovascular risk factors such as diabetes, hypertension, and dyslipidemia, bariatric surgery is associated with reduced cardiovascular mortality and morbidity in obese adults. Our study validates once more these beneficial effects of weight loss through bariatric surgery and confirms a link between weight and inflammatory status, as shown by the linear correlation obtained for weight, respectively BMI and fibrinogen.

In future studies, expanding the number of patients, using a longer follow-up period and further exploring the evolution of the inflammatory status might give us a better impression on the long-term effects of bariatric surgery.

\section{Conflict of Interest}

The authors declare no conflicts of interests.

\section{Author's Contributions}

L.E. - study design, statistical analysis and writing of the original draft, M.P. - software, statistical analysis, reviewing of the original draft and editing, C.C. - validation, supervision, D.D., D.G., C.C. - reviewing and editiong.

\section{References}

1. Hales CM, Carroll MD, Fryar CD, Ogden CL. Prevalence of Obesity Among Adults and Youth: United States, 2015-2016. NCHS Data Brief. 2017;(288):1-8.

2. Afshin A, Forouzanfar MH, Reitsma MB, Sur P, Estep K, Lee A, et al. Health effects of overweight and obesity in 195 countries over 25 years. N Engl J Med. 2017;377(1):13-27.

3. Whitlock G, Lewington S, Sherliker P, Clarke R, Emberson J, Halsey $\mathrm{J}$, et al. Body-mass index and cause-specific mortality in
900000 adults: Collaborative analyses of 57 prospective studies. Lancet. 2009;373(9669):1083-1096.

4. Aune D, Sen A, Prasad M, Norat T, Janszky I, Tonstad S, et al. BMI and all cause mortality: Systematic review and non-linear doseresponse meta-analysis of 230 cohort studies with 3.74 million deaths among 30.3 million participants. BMJ. 2016;353:i2156.

5. MacMahon S, Baigent C, Duffy S, et al. Body-mass index and cause-specific mortality in 900000 adults: Collaborative analyses of 57 prospective studies. Lancet. 2009;373(9669):1083-1096.

6. Park YW, Zhu S, Palaniappan L, Heshka S, Carnethon MR, Heymsfield SB. The metabolic syndrome: Prevalence and associated risk factor findings in the US population from the Third National Health and Nutrition Examination Survey, 1988-1994. Arch Intern Med. 2003;163(4):427-436.

7. Bays HE, Chapman RH, Grandy S, SHIELD Investigators' Group. The relationship of body mass index to diabetes mellitus, hypertension and dyslipidaemia: comparison of data from two national surveys. Int J Clin Pract. 2007;61(5):737-747.

8. Sjöström L, Peltonen M, Jacobson P, Sjöström CD, Karason K, Wedel $\mathrm{H}$, et al. Bariatric surgery and long-term cardiovascular events. JAMA - J Am Med Assoc. 2012;307(1):56-65.

9. Willett WC, Manson JE, Stampfer MJ, Colditz GA, Rosner B, Speizer FE, et al. Weight, Weight Change, and Coronary Heart Disease in Women: Risk Within the "Normal" Weight Range. JAMA J Am Med Assoc. 1995;273(6):461-465.

10. Brolin RE, Kenler HA, Wilson AC, Kuo PT, Cody RP. Serum lipids after gastric bypass surgery for morbid obesity. Int J Obes. 1990; 14(11):939-950.

11. Ikramuddin S, Korner J, Lee WJ, Connett JE, Inabnet WB, Billington CJ, et al. Roux-en-Y gastric bypass vs intensive medical management for the control of type 2 diabetes, hypertension, and hyperlipidemia: The diabetes surgery study randomized clinical trial. JAMA - J Am Med Assoc. 2013; 309(21):2240-2249.

12. Jamal M, Wegner R, Heitshusen D, Liao J, Samuel I. Resolution of hyperlipidemia follows surgical weight loss in patients undergoing Roux-en-Y gastric bypass surgery: A 6-year analysis of data. Surg Obes Relat Dis. 2011;7(4):473-479.

13. Nguyen NT, Varela E, Sabio A, Tran CL, Stamos M, Wilson SE. Resolution of Hyperlipidemia after Laparoscopic Roux-en-Y Gastric Bypass. J Am Coll Surg. 2006;203(1):24-29.

14. Rubino F. Is type 2 diabetes an operable intestinal disease? A provocative yet reasonable hypothesis. Diabetes Care. 2008;31 Suppl 2.

15. Schauer PR, Nor Hanipah Z, Rubino F. Metabolic surgery for treating type 2 diabetes mellitus: Now supported by the world's leading diabetes organizations. Cleve Clin J Med. 2017;84(7 Suppl 1):S47-S56.

16. Liou AP, Paziuk M, Luevano JM, Machineni S, Turnbaugh PJ, Kaplan LM. Conserved shifts in the gut microbiota due to gastric bypass reduce host weight and adiposity. Sci Transl Med. 2013;5(178).

17. Osto E, Doytcheva P, Corteville C, Bueter M, Dörig C, Stivala S, et al. Rapid and body weight-independent improvement of endothelial and high-density lipoprotein function after Roux-en-Y gastric bypass role of glucagon-like peptide-1. Circulation. 2015;131(10): 871-881.

18. Guimarăes M, Rodrigues $P$, Pereira SS, Nora M, Gonçalves G, Albrechtsen NW, et al. GLP1 and glucagon co-secreting pancreatic neuroendocrine tumor presenting as hypoglycemia after gastric bypass. Endocrinol Diabetes Metab Case Rep. 2015;150049.

19. Schiavon CA, Bersch-Ferreira AC, Santucci EV, Dantas Oliveira J, Ragne Torreglosa C, Torres Bueno P, et al. Effects of bariatric surgery in obese patients with hypertension the GATEWAY randomized trial (gastric bypass to treat obese patients with steady hypertension). Circulation. 2018;137(11):1132-1142.

20. Jakobsen GS, Smțstuen MC, Sandbu R, Nordstrand N, Hofsø D, Lindberg M, et al. Association of Bariatric Surgery vs Medical Obesity Treatment With Long-term Medical Complications and Obesity-Related Comorbidities. JAMA. 2018;319(3):291-301. 